\title{
Technological quality and composition of the $M$. semimembranosus and $M$. longissimus dorsi from Large White and Landrace Pigs
}

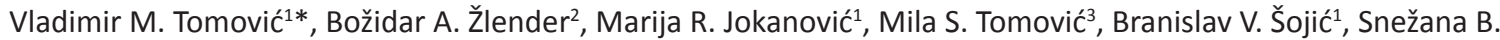 \\ Škaljac ${ }^{1}$, Tatjana A. Tasić ${ }^{4}$, Predrag M. Ikonić ${ }^{4}$, Milena M. Šošo ${ }^{1}$ and Nevena M. Hromiš ${ }^{1}$ \\ ${ }^{1}$ University of Novi Sad, Faculty of Technology, Bulevar cara Lazara 1, 21000 Novi Sad, Serbia \\ ${ }^{2}$ University of Ljubljana, Biotechnical faculty, Jamnikarjeva 101, 1000 Ljubljana, Slovenia \\ ${ }^{3}$ Technical school "Pavle Savić", Šajkaška 34, 21000 Novi Sad, Serbia \\ ${ }^{4}$ University of Novi Sad, Institute for Food Technology, Bulevar cara Lazara 1, 21000 Novi Sad, Serbia \\ e-mail: tomovic@uns.ac.rs
}

\begin{abstract}
The effects of pig breed (Large White and Landrace) in combination with muscle type (M. semimembranosus and M. longissimus dorsi) on $\mathrm{T}_{45 \text { min }}, \mathrm{T}_{24 \mathrm{~h}}, \mathrm{pH}_{45 \mathrm{~min}}, \mathrm{pH}_{24 \mathrm{~h}}$, colour (CIEL ${ }^{*}{ }^{*} b^{*}$ values), water-holding capacity (filter paper press method: ratio of the area of pressed meat film $-M$ and the wet area on the filter paper $-T ; M / T$ value) and moisture, protein, total fat and total ash content were investigated. Interaction effect between breed and muscle was not found $(p>0.05)$ for any parameter. The $T_{45 \mathrm{~min}^{\prime}} \mathrm{T}_{24 \mathrm{~h}^{\prime}}, \mathrm{pH}_{45 \min ^{\prime}}$ and $\mathrm{M} / \mathrm{T}$ value were influenced by the muscle,

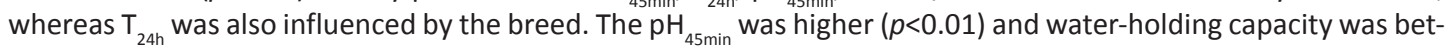
ter $(p<0.001)$ in $M$. semimembranosus muscle than in M. longissimus dorsi muscle. Based on the criteria for CIEL* and $\mathrm{M} / \mathrm{T}$ values, pork meat was classified into seven technological quality classes. The percentages of pale and exudative, reddish-pink and exudative, and reddish-pink and non-exudative pork were $23.5,26.5$, and $27.7 \%$, respectively. Composition was in the characteristic range for modern lean pigs.
\end{abstract}

Key words: pig, Large White, Landrace, M. semimembranosus, M. longissimus dorsi, technological quality, composition

\section{Introduction}

The technological quality attributes of meat include: $\mathrm{pH}$ value, color, texture, water-holding capacity (WHC) and chemical composition (Rosenvold and Andersen 2003, Olsson and Pickova 2005, Sevón-Aimonen et al. 2007). These parameters are influenced by multiple interacting factors including breed, genetics, feeding, pre-slaughter treatment and stunning, slaughter method, chilling and storage conditions, as reviewed by Rosenvold and Andersen (2003).

It is believed that $\mathrm{pH}$ is one of the keys to understanding post-mortem muscle glycolysis. A number of authors report that the rate of post-mortem $\mathrm{pH}$ fall is an important determinant of colour and WHC. An abnormally rapid rate of glycolysis early post-mortem in the muscles produces poor pork quality (pale and exudative meat). On the other hand, higher ultimate $\mathrm{pH}$ is associated with darker colour and better WHC (Bendall and Swatland 1988, Brewer et al. 2001, Lawrie and Ledward 2006).

Fresh pork has been traditionally classified into three technological quality categories, according to the measurements of pH value, colour, firmness (texture) and drip loss (exudation): PSE (pale, soft, exudative), RFN (reddish-pink, firm, non-exudative or normal pork) and DFD (dark, firm, dry). The RFN meat is considered the ideal pork quality class (Kauffman et al. 1992, Joo et al. 2000a). Pork meat that is classified as RFN has a desirable color, normal texture and WHC. One of the most important and the most frequently found quality deviation of pork meat is a PSE defect (Bendall and Swatland 1988, Kauffman et al. 1992, Warner et al. 1997, Joo et al. 2000a, O'Neill et al. 2003, van de Perre et al. 2010). On the other hand, the incidence of DFD meat is low and less relevant to industry (Bendall and Swatland 1988, Kauffman et al. 1992, van Laack et al. 1994, O'Neill et al. 2003, van de Perre et al. 2010). 
V.M. Tomovic et al. (2014) 23: 9-18

The development of PSE is caused by excessive protein denaturation due to a combination of a low $\mathrm{pH}$ and a high muscle temperature early post-mortem. The opposite of PSE is DFD muscle, which is caused by a depletion of glycogen content at the time of slaughter, resulting in a high ultimate $\mathrm{pH}_{24 \mathrm{~h}}$ and a higher susceptibility to the microbiological spoilage (Bendall and Swatland 1988, Warner et al. 1997, Lawrie and Ledward 2006, Barbut et al. 2008).

Beside these three traditional categories, during the last two decades many authors introduced two additional intermediate quality variations: RSE (reddish-pink, soft, exudative) and PFN (pale, firm, non-exudative). RSE pork has normal color, but a soft texture and an exudative character similar to PSE, whereas PFN pork has the texture of meat of good quality, but has undesirable color, similar to PSE (Kauffman et al. 1992, van Laack et al. 1994, Warner et al. 1997, Joo et al. 2000a, O'Neill et al. 2003). Over the years RSE and PFN have also been recognized as serious quality defects (Kauffman et al. 1992, van Laack et al. 1994, Joo et al. 2000a, O’Neill et al. 2003, van de Perre et al. 2010).

Incidence of inferior muscle quality, especially with PSE and RSE defects, has an economic impact in the pork industry (Kauffman et al. 1992, Joo et al. 2000a, O’Neill et al. 2003, Huff-Lonergan and Lonergan 2005, Sevón-Aimonen et al. 2007). For this reason, evaluation of technological quality of pork represents an important step in meat production and processing.

In international practice the evaluation of pork quality is based on very different parameters and criteria. The most popular parameters, which enable identification of defective meat, include the $\mathrm{pH}$ value, measured in the muscle tissue 30-60 minutes (pre-rigor state) and 24 hours post-mortem (post-rigor state), meat colour (reflectance - lightness - CIEL* value) and WHC (numerous analytical methodologies: filter paper press, filter paper, bag, tray, EZ-DripLoss, absorption or centrifugation methods or determination of cooking loss), measured 24 hours postmortem (Bendall and Swatland 1988, Honikel 1998, 1999, Sevón-Aimonen et al. 2007). Moreover, other parameters like: electrical conductivity (Joo et al. 2000a, Lee et al. 2000) or impedance (Swatland 1995) help to identify defects in pork meat quality (Bendall and Swatland 1988, Honikel 1999). Characteristics should be easily measurable, what means that a destructive cutting of a carcass must not occur. Therefore, the easy accessible M. semimembranosus and $M$. longissimus dorsi are recommended as representative muscles (Honikel 1999).

The measurement of $\mathrm{pH}$ values is the most direct way to obtained information about meat quality characteristics. The $\mathrm{pH}_{45 \min }$ identifies potential PSE pork, especially if the value is less than 6.0 (Bendall and Swatland 1988, O'Neill et al. 2003, Lawrie and Ledward 2006). However, CIEL* value is probably the best overall indicator for PSE and DFD pork (Brewer et al. 2001).

Skeletal muscle tissue is composed of approximately $75.0 \%$ water, $19.0 \%$ protein, $2.5 \%$ lipid, $1.5 \%$ non-protein nitrogenous compounds, $1.0 \%$ carbohydrate and non-nitrogenous components and $1.0 \%$ inorganic matter (Keeton and Eddy 2004, Lawrie and Ledward 2006). Meat tissue composition varies according to differences in species, chronological and physiological maturity at harvest, plane of nutrition, genetic predisposition, and anatomical location of cuts (muscles) within a carcass (Keeton and Eddy 2004, Olsson and Pickova 2005, Lawrie and Ledward 2006).

The Autonomous Province of Vojvodina (the northern part of the Republic of Serbia) is a region where the number of animals of the porcine species and the production of pork meat are of high economic importance. The most common white purebreds of pigs used in Vojvodina, as well as in Serbia, for pork production are the Large White and the Landrace. Also, they are commonly used in crossbreeding programs. This cross is often used as the female line in commercial herds. Dark purebreds such as Duroc, Hampshire or Pietrain are often used as a male line (Lawrie and Ledward 2006, Sevón-Aimonen et al. 2007, The Danish Standard 2007, Barbut et al. 2008, Tomović et al. 2011).

The objective of this study was to determine the technological quality ( $\mathrm{pH}$, colour $-\mathrm{CIEL}^{*} a^{*} b^{*}$ values and WHC - M/T value - filter paper press method) and composition (moisture, protein, total fat and total ash content) of two economically most important muscles ( $M$. semimembranosus and $M$. longissimus dorsi) from two major white purebreds (Large White and Landrace) used for pork production in Vojvodina (Republic of Serbia). Based on the criteria for colour (CIEL* value) and WHC (M/T value), data of this study were used to classify pork quality into different categories. 


\title{
Materials and methods
}

\author{
Animals, sampling, slaughter and preparing
}

This study was carried out on 81 (females and castrated males) Large White (LW) and 83 (females and castrated males) Landrace (L) pigs. The pigs were fattened at the 4 production farms in Vojvodina under identical conditions (Tomović et al. 2011). The pigs were randomly selected from both purebreds at an individual live weight between 95 and $110 \mathrm{~kg}$, and about 6 months old. Four to five pigs from both breeds fattened at the same farm were taken during one production day per week for a total of 20 weeks. All the pigs were slaughtered in the two biggest slaughterhouses in Vojvodina according to routine procedures. After transport, which took 1-2 hours, pigs were allowed to rest for about 2-3 hours in the abattoir. Stunning was performed electrically (220 V, 2 A, 8-12 seconds) in a V-restrainer with a pair of stunning tongs. After stunning, the animals were shackled by one hind leg and exsanguinated and scalded $\left(5\right.$ minutes, $62^{\circ} \mathrm{C}$ ) vertically. Carcasses were then individually placed in a dehairer and any remaining hair was removed using flame and knife. The evisceration was finished about 45 minutes postmortem. Carcasses were conventionally chilled for 24 hours in a chiller at $0-4{ }^{\circ} \mathrm{C}$.

M. semimembranosus (SM) and $M$. longissimus dorsi (LD) were excised from the right side of each carcass. Identification of the muscles was performed according to UNECE (2008). The meat samples were trimmed of visible adipose and connective tissue. Technological quality characteristics were measured on fresh muscles (SM muscle: central part, LD muscle: central part between 3rd and 4th from the last rib). After determination of technological quality characteristics, each muscle was homogenized (Waring 8010ES Blender, USA, capacity: 1 liter, speed: $18000 \mathrm{rpm}$, duration of homogenization: 10 seconds, temperature after homogenization: $<10{ }^{\circ} \mathrm{C}$ ), vacuum packaged in polyethylene bags and stored at $-40{ }^{\circ} \mathrm{C}$ until determination of composition. Composition of SM and LD muscles for 40 pigs from each purebred was determined.

\section{Technological quality measurements}

Temperature was measured at the start 45 minutes $\left(T_{45 \min }\right)$ post-mortem and at the end 24 hours $\left(T_{24 h}\right)$ post-mortem of the chilling process in the SM muscles, and in the LD muscles, on the right side of every carcass, using a portable digital thermometer with a $12 \mathrm{~cm}$ stem (Consort T651, Turnhout, Belgium).

The $\mathrm{pH}$ value was measured 45 minutes $\left(\mathrm{pH}_{45 \min }\right)$ and 24 hours $\left(\mathrm{pH}_{24 \mathrm{~h}}\right)$ post-mortem using the portable $\mathrm{pH}$ meter (Consort T651, Turnhout, Belgium) equipped with an insertion glass combination electrode (Mettler Toledo Greifensee, Switzerland). The $\mathrm{pH}$ meter was calibrated before and between the measurements using standard phosphate buffers ( $\mathrm{pH}$ values of calibration buffers were 7.00 and 4.01 at $25^{\circ} \mathrm{C}$ ) and adjusted to the expected temperature of measured muscles (ISO 2917 1999). Measurements were performed in triplicate.

Based on the initial $\mathrm{pH}$ (45 minutes post-mortem) the pork quality was classified as potential PSE $(\mathrm{pH}<6.0)$ or normal $(\mathrm{pH} \geq 6.0)$. On the other hand, based on the ultimate $\mathrm{pH}(24$ hours post-mortem) the pork quality was classified as normal $(\mathrm{pH}<6.0)$ or DFD ( $\mathrm{pH} \geq 6.0$ ) (Kauffman et al. 1992, Warner et al. 1997, Joo et al. 2000a, O’Neill et al. 2003, Lawrie and Ledward 2006).

After chilling samples for colour measurements were taken perpendicularly to the long axis of muscle, the minimum thickness of samples was $2.5 \mathrm{~cm}$. Eight replicate measures of surface colour were performed on each sample, after 60 minutes of blooming at $3{ }^{\circ} \mathrm{C}$ (Honikel 1998). The CIEL* (lightness), CIEa* (redness) and CIEb* (yellowness) colour coordinates (CIE 1976) were determined using MINOLTA Chroma Meter CR-400 (Minolta Co. Ltd. Osaka, Japan) with D-65 lighting, a $2^{\circ}$ standard observer angle and the 8-mm aperture in the measuring head. The instrument was calibrated using a Minolta calibration plate (No. 11333090, $Y=92.9, x=0.3159, y=0.3322$ ). The colour quality was calculated on the basis of all individual lightness (CIEL* value) measurements, according to criteria for pork (pale colour: $\mathrm{CIEL}^{*}>50$, reddish-pink colour: $\mathrm{CIEL}{ }^{*}=43-50$, dark colour: $\mathrm{CIE} L^{*}<43$ ) as defined by Joo et al. (1999), Joo et al. (2000a, 2000b), Tomović et al. (2008) and Tomović et al. (2013).

Determination of the water-holding capacity (WHC) was based on measuring water released when pressure was applied to the muscle tissue (exudative juice). Exudative juice was assessed using a filter paper press method (Grau and Hamm 1953, van Oeckel et al. 1999). A cube of $300 \pm 25 \mathrm{mg}$ of meat from the inside of the muscle sample was placed on a filter paper (Schleicher \& Schull No. 2040 B, Dassel, Germany) between two plexiglas plates. Plates were then screwed together tightly for exactly 5 minutes. The analysis was performed in triplicate. The WHC was expressed as the ratio of the area of pressed meat film (M) and the wet area on the filter paper (T), as determined by mechanical polar planimeter (REISS Precision 3005, Bad Liebenwerda, Germany). The WHC quality was calculated on the basis of all individual $\mathrm{M} / \mathrm{T}$ values measurements, according to criteria for pork (exudative meat: $\mathrm{M} / \mathrm{T}<0.35$, 
non-exudative meat: $\mathrm{M} / \mathrm{T}=0.35-0.45$, dry meat: $\mathrm{M} / \mathrm{T}>0.45$ ) as defined by Hofmann et al. (1982). Thus, combining three criteria for colour and three criteria for WHC technological pork quality was classified into 9 quality classes.

\section{Composition}

Moisture (ISO 1442 1997), protein (nitrogen x 6.25, ISO 937 1978), total fat (ISO 1443 1973) and total ash (ISO 936 1998) contents of muscles were determined according to methods recommended by International Organization for Standardization. All analyses were performed in duplicate.

\section{Statistical analysis}

All data are presented as mean and standard deviation (SD). Data were analyzed statistically with factorial ANOVA and post-hoc test (Dunckan's test). Two-way analysis of variance was performed; 2 breeds x 2 muscles. Levels of significance $p<0.05, p<0.01$, and $p<0.001$ were used. Correlation coefficients among quality characteristics of pork were also calculated. Statistical analysis was conducted using Statistica software version 10 (StatSoft, Inc. 2011).

\section{Results and discussion}

\section{Overall technological quality of pork}

No significant $(p>0.05)$ interaction effect between breed and muscle type was found for all determined technological parameters (Table 1 ).

The initial (45 minutes post-mortem) mean temperatures in the SM muscles of both LW and L breeds were 40.2 and $40.1^{\circ} \mathrm{C}$, respectively (Table 1 ). At the same time, in the LD muscles significantly lower mean temperatures $(p<0.001)$ were found than those in the SM muscles, within each breed, i.e. initial temperature was significantly influenced by the type of the muscle. Difference between mean temperatures in SM and LD muscles for both breeds was identical, $1.5^{\circ} \mathrm{C}$. Similarly, at the end of chilling (24 hours post-mortem), mean temperatures in LD muscles were significantly lower $(p<0.001)$ than those in the SM muscles. Ultimate temperature was also significantly $(p<0.001)$ influenced by the breed. Mean ultimate temperatures ranged from 2.9 (LD of L) to $5.0^{\circ} \mathrm{C}(\mathrm{SM}$ of $\mathrm{LW}$ ). All the individual ultimate temperatures were lower or equal $7{ }^{\circ} \mathrm{C}$. According to EU Council Directives (ECC No. 433/1964), as well as Serbian Regulation (2011), pork must not be cut and deboned before reaching $7{ }^{\circ} \mathrm{C}$ in the deep leg.

Table 1. Mean values ( \pm SD) of the technological quality of $M$. semimembranosus (SM) and M. longissimus dorsi (LD) of Large White (LW) and Landrace (L) pigs.

\begin{tabular}{|c|c|c|c|c|c|c|c|}
\hline \multirow{4}{*}{ Parameter } & \multicolumn{4}{|c|}{ Breed } & \multirow{2}{*}{\multicolumn{3}{|c|}{$p$-value }} \\
\hline & \multicolumn{2}{|c|}{ LW } & \multicolumn{2}{|c|}{$\mathrm{L}$} & \multirow{3}{*}{ Breed } & & \multirow{3}{*}{$\begin{array}{l}\text { Breed } x \\
\text { Muscle }\end{array}$} \\
\hline & \multicolumn{2}{|c|}{ Muscle } & \multicolumn{2}{|c|}{ Muscle } & & \multirow{2}{*}{ Muscle } & \\
\hline & SM & LD & SM & LD & & & \\
\hline \multicolumn{8}{|c|}{ Initial and ultimate temperature $\left({ }^{\circ} \mathrm{C}\right)$} \\
\hline $\mathrm{T}_{45 \mathrm{~min}}$ & $40.2^{\mathrm{aov}} \pm 0.34$ & $38.7^{\mathrm{bpw}} \pm 0.54$ & $40.1^{\mathrm{aov}} \pm 0.40$ & $38.6^{\mathrm{bpw}} \pm 0.60$ & 0.175 & $<0.001$ & 0.916 \\
\hline$T_{24 h}$ & $5.0^{\mathrm{aov} \pm 1.28}$ & $3.2^{\mathrm{cax}} \pm 0.84$ & $4.3^{\mathrm{bpw}} \pm 1.40$ & $2.9^{\mathrm{cqx}} \pm 0.88$ & $<0.001$ & $<0.001$ & 0.148 \\
\hline \multicolumn{8}{|c|}{ Initial and ultimate $\mathrm{pH}$} \\
\hline $\mathrm{pH}_{45 \min }$ & $6.26^{\mathrm{a} 0} \pm 0.27$ & $6.16^{\mathrm{bop}} \pm 0.26$ & $6.20^{\mathrm{abop}} \pm 0.26$ & $6.14^{\mathrm{bp}} \pm 0.30$ & 0.165 & 0.008 & 0.556 \\
\hline $\mathrm{pH}_{24 \mathrm{~h}}$ & $5.78 \pm 0.20$ & $5.74 \pm 0.21$ & $5.72 \pm 0.20$ & $5.70 \pm 0.24$ & 0.056 & 0.255 & 0.801 \\
\hline \multicolumn{8}{|l|}{ Colour } \\
\hline CIEL* (lightness) & $48.11 \pm 3.97$ & $48.72 \pm 3.64$ & $47.99 \pm 3.92$ & $49.31 \pm 4.56$ & 0.598 & 0.052 & 0.423 \\
\hline $\mathrm{CIE} a^{*}$ (redness) & $10.91 \pm 2.33$ & $10.91 \pm 1.82$ & $11.04 \pm 2.13$ & $10.12 \pm 2.41$ & 0.183 & 0.058 & 0.057 \\
\hline CIE $b^{*}$ (yellowness) & $6.76 \pm 2.48$ & $6.31 \pm 2.28$ & $6.78 \pm 1.91$ & $6.70 \pm 2.41$ & 0.418 & 0.295 & 0.468 \\
\hline \multicolumn{8}{|c|}{ Water-holding capacity } \\
\hline $\mathrm{M} / \mathrm{T}$ & $0.38^{\mathrm{aov}} \pm 0.07$ & $0.33^{\mathrm{bpw}} \pm 0.07$ & $0.36^{\mathrm{aovw}} \pm 0.07$ & $0.33^{\mathrm{bpw}} \pm 0.06$ & 0.139 & $<0.001$ & 0.316 \\
\hline
\end{tabular}

abcindicates significant difference within raw at $p<0.05$, opaindicates significant difference within raw at $p<0.01$, vwxindicates significant difference within raw at $p<0.001$.

$\mathrm{M}=$ area of the pressed meat film; $\mathrm{T}$ = wet area on the filter paper. 
V.M. Tomovic et al. (2014) 23: 9-18

Initial $\mathrm{pH}$ value was significantly influenced $(p=0.008)$ by the type of the muscle (Table 1$)$. In the SM muscles initial $\mathrm{pH}$ values were significantly (LW breed, $p<0.05$ ) or numerically ( $\mathrm{L}$ breed, $p>0.05$ ) higher than those in the LD muscles. In SM muscles from LW and L breeds, the mean initial (45 minutes post-mortem) pH values were 6.26 and 6.20, respectively, while in LD muscles these values were 6.16 and 6.14, for LW and L breeds, respectively. Similarly, at the end of chilling (24 hours post-mortem), mean ultimate $\mathrm{pH}$ in SM muscles were numerically higher than those in LD muscles within each breed. However, ultimate $\mathrm{pH}$ was not significantly influenced $(p>0.05)$ by the type of muscle. All mean ultimate $\mathrm{pH}$ values, which ranged from 5.70 (LD of L) to 5.78 (SM of LW), were in the characteristic range for pork (5.3-5.8; Smulders et al. 1992, Honikel 1999). As expected (Table 2), in the present study the $\mathrm{pH}_{45 \mathrm{~min}}$ was significantly positively correlated with the $\mathrm{pH}_{24 \mathrm{~h}}(\mathrm{r}=0.42$ for $\mathrm{LW}$ and $\mathrm{r}=0.48$ for $\mathrm{L}, p<0.001)$.

$\mathrm{CIEL}{ }^{*} a^{*} b^{*}$ values (lightness, redness and yellowness) were not significantly influenced $(p>0.05)$ by the type of muscle (Table 1). The highest (lightest colour) and the lowest (darkest colour) numerical CIEL* mean values were found in LD and SM muscles of L breed. These values were 49.31 for the LD and 47.99 for the SM muscle. According to the mean values for lightness (CIEL* value), the colour of all investigated groups of SM and LD muscles represent normal meat quality (reddish-pink colour: $\mathrm{CIEL}^{*}=43-50$, Joo et al. 1999, Joo et al. 2000a 2000b, Tomović et al. 2008, Tomović et al. 2013). Furthermore, the mean CIEa* values (redness) ranged from 10.12 (LD of L) to 11.04 (SM of L). Almost identical mean $\mathrm{CIE} b^{*}$ values were determined in all investigated groups of muscles. The mean $\mathrm{CIE} b^{*}$ value ranged from 6.31 (LD of $\mathrm{LW}$ ) to 6.78 (SM of L).

WHC (M/T value) was significantly influenced $(p<0.001)$ by the type of muscle (Table 1$)$. For both breeds, SM muscles had significantly better WHC (M/T=0.38 for $\mathrm{LW}$ and 0.36 for $\mathrm{L}$, a bigger $\mathrm{M} / \mathrm{T}$ ratio indicating a better WHC) than $L D$ muscles ( $M / T=0.33$, for both breeds). According to the mean $M / T$ values, the $W H C$ of both SM groups of muscles represent normal meat quality (non-exudative meat: $M / T=0.35-0.45$, Hofmann et al. 1982), while both LD groups of muscles represent poor pork quality (exudative meat: $M / T<0.35$, Hofmann et al. 1982).

As expected (Table 2), $\mathrm{pH}_{45 \min }$ and $\mathrm{pH}_{24 \mathrm{~h}}$ were significantly negatively correlated with $\mathrm{CIEL}$ * value $(\mathrm{r}=-0.29$ and $\mathrm{r}=-$ 0.58 , respectively, for $L W, p<0.001 ; r=-0.50$ and $r=-0.61$, respectively, for $L, p<0.001$ ) and significantly positively correlated with $M / T$ value $(r=0.27$ and $r=0.37$, respectively, for $L W, p<0.001 ; r=0.39$ and $r=0.29$, respectively, for $\mathrm{L}, p<0.001)$. Additionally, $\mathrm{CIEL}$ * value was significantly negatively correlated with $\mathrm{M} / \mathrm{T}$ value $(\mathrm{r}=-0.52$ for $\mathrm{LW}$ and $r=-0.47$ for $L, p<0.001)$. These correlations are in agreement with Bendall and Swatland (1988), van Laack et al. (1994), Lee et al. (2000), Brewer et al. (2001) and van de Perre et al. (2010).

Table 2. Overall correlation coefficients ( $r$ ) among technological quality parameters of Large White (LW) and Landrace (L) pigs.

\begin{tabular}{|c|c|c|c|c|c|c|}
\hline \multirow[b]{2}{*}{ Parameter } & \multicolumn{3}{|c|}{ Breed - LW } & \multicolumn{3}{|c|}{ Breed - L } \\
\hline & $\mathrm{pH}_{24 \mathrm{~h}}$ & CIEL* & $\mathrm{M} / \mathrm{T}$ & $\mathrm{pH}_{24 \mathrm{~h}}$ & CIEL* & $\mathrm{M} / \mathrm{T}$ \\
\hline $\mathrm{pH}_{45 \min }$ & $0.42 * * *$ & $-0.29 * * *$ & $0.27 * * *$ & $0.48 * * *$ & $-0.50 * * *$ & $0.39 * * *$ \\
\hline $\mathrm{pH}_{24 \mathrm{~h}}$ & & $-0.58^{* * *}$ & $0.37^{* * *}$ & & $-0.61 * * *$ & $0.29 * * *$ \\
\hline CIEL* & & & $-0.52 * * *$ & & & $-0.47 * * *$ \\
\hline
\end{tabular}

$* * *$ indicates significant difference at $p<0.001$.

$\mathrm{M}=$ area of the pressed meat film; $\mathrm{T}=$ wet area on the filter paper.

\section{Incidence of different technological quality classes of pork}

According to criteria for initial $\mathrm{pH}\left(\mathrm{pH}_{45 \min }<6.0\right)$, in this study, the percentage of potential PSE pork was $14.8 \%$ for SM of LW, $28.4 \%$ for LD of LW, $24.1 \%$ for SM of L and $27.7 \%$ for LD of L (Table 3). Overall, based on criteria for $\mathrm{pH}_{45 \text { min }}, 23.8 \%$ of investigated muscles were potentially classified as PSE. In addition, the percentage of DFD pork with $\mathrm{pH}_{24 h} \geq 6.0$ (Kauffman et al. 1992, Warner et al. 1997, Joo et al. 2000a 2000b, O'Neill et al. 2003) was 13.6\% for SM of LW, $14.8 \%$ for LD of LW, $12.0 \%$ for SM of L, and $15.7 \%$ for LD of L. Overall, based on criteria for $\mathrm{pH}_{24 \mathrm{~h}^{\prime}}$ $14.0 \%$ of investigated muscles were classified as DFD.

In this study, the colour of SM and LD muscles was defined as pale when ultimate $\mathrm{CIEL} L^{*}>50$, reddish-pink when ultimate CIEL ${ }^{*}=43-50$ or dark when ultimate CIEL ${ }^{*}<43$ (Table 3). The highest incidence of the pale (43.4\%) and dark $(10.8 \%)$ colour and lowest incidence of reddish-pink (45.8\%) colour was found in LD muscles of $L$ breed. The incidence of pale, reddish-pink and dark colour in other three investigated groups of muscles were similar, i.e. the incidence of pale colour ranged from 29.6\% (SM of LW) to 33.3\% (LD of LW), reddish-pink ranged from 60.5\% (LD of $L W$ ) to $62.7 \%$ (SM of $L$ ) and dark ranged from $6.2 \%$ (LD of $L W$ ) to $8.6 \%$ (SM of LW). Overall, based on criteria for 
V.M. Tomovic et al. (2014) 23: 9-18

$\mathrm{CIE} L^{*}, 34.1 \%$ of investigated muscles were classified as pale pork $\left(\mathrm{CIEL} L^{*}>50\right), 57.6 \%$ as reddish-pink pork $\left(\mathrm{CIE} L^{*}=\right.$ 43-50), and $8.2 \%$ as dark pork $\left(C I E L^{*}<43\right)$.

Combining criteria for $\mathrm{pH}_{45 \min }$ and $\mathrm{CIEL}^{*}$ value to define pork quality of each individual SM and LD muscle, it was calculated that $62.8 \%$ of muscles with $\mathrm{pH}_{45 \mathrm{~min}}<6.0$ had CIEL ${ }^{*}$ value higher than 50 (calculated data are not shown). Also, the incidence of pale $\left(\mathrm{CIEL}^{*}>50\right)$ colour in all investigated groups of SM and LD muscles was higher than the incidence of the initial $\mathrm{pH}$ below 6.0 (Table 3). In addition, combining criteria for $\mathrm{pH}_{24 \mathrm{~h}}$ and $\mathrm{CIEL}^{*}$ value to define pork quality on each individual SM and LD muscle, it was calculated that $34.8 \%$ of muscles with $\mathrm{pH}_{24 \mathrm{~h}} \geq 6.0$ had CIEL* value lower than 43 (calculated data are not shown). Also, the incidence of dark (CIEL*<43) colour in all investigated groups of SM and LD muscles was lower than the incidence of the ultimate pH above 6.0 (Table 3).

In this study, according to WHC, SM and LD muscles were defined as exudative when M/T value $<0.35$, non-exudative when $\mathrm{M} / \mathrm{T}$ value between $0.35-0.45$ or dry when $\mathrm{M} / \mathrm{T}$ value $>0.45$ (Table 3 ). The incidence of non-exudative pork in SM and LD muscles from both breeds was very similar (53.1\% of SM : 37.0\% of LD from LW versus $51.8 \%$ of SM : $37.3 \%$ of LD from L). Compared to incidence of non-exudative pork, the incidence of exudative pork in SM muscles was $34.8 \%$ lower for LW and $13.9 \%$ for L, while the incidence of exudative pork in LD muscles was $60.3 \%$ higher for LW and $64.6 \%$ for L. The highest incidence of dry pork was found in SM muscles of LW breed (12.3\%), and the lowest in LD muscles of $L$ breed (1.2\%). Overall, based on criteria for $M / T$ value, $50.0 \%$ of investigated muscles were classified as exudative pork $(\mathrm{M} / \mathrm{T}<0.35), 44.8 \%$ as non-exudative pork $(\mathrm{M} / \mathrm{T}=0.35-0.45)$ and $5.2 \%$ as dry pork (M/T>0.45).

Combining criteria for $\mathrm{pH}_{45 \min }$ and $\mathrm{WHC}$ to define pork quality of each individual SM and LD muscles, it was calculated that $71.8 \%$ of muscles with $\mathrm{pH}_{45 \min }<6.0$ had $\mathrm{M} / \mathrm{T}$ value lower than 0.35 (calculated data are not shown). Further, the incidence of exudative pork $(\mathrm{M} / \mathrm{T}<0.35)$ in all investigated groups of SM and LD muscles was higher than the incidence of the initial pH below 6.0 (Table 3). In addition, combining criteria for $\mathrm{pH}_{24 \mathrm{~h}}$ and $\mathrm{WHC}$ to define pork quality of each individual SM and LD muscles it was calculated that $13.0 \%$ of muscles with $\mathrm{pH}_{24 h} \geq 6.0$ had $\mathrm{M} / \mathrm{T}$ value higher than 0.45 (calculated data are not shown). Also, the incidence of dry pork $(\mathrm{M} / \mathrm{T}>0.45)$ in all investigated groups of SM and LD muscles was lower to the incidence of the ultimate pH above 6.0 (Table 3).

The results of this study are in accordance with the conclusion of Bendall and Swatland (1988), van Laack et al. (1994), Joo et al. (1999) and Joo et al. (2000a 2000b) that the initial and ultimate pH values were not always a reliable predictor for ultimate pork quality and its relation to both color and WHC of pork muscle should be more carefully investigated, although it is evident that $\mathrm{pH}$ values are significantly related to both colour and WHC (Table 2).

The detection of different pork quality is an important issue for meat industry in order to reduce economic losses and to proportionate the best destination to fresh meat. Generally, PSE/DFD meat is identified on the base of $\mathrm{pH}$ value, colour (CIEL* value) and WHC. While in some cases PSE/DFD meat is identified only on the base of colour (CIEL* value) and WHC (van Laack et al. 1994, Joo et al. 1999, Joo et al. 2000a 2000b).

In this paper, colour (CIEL* value) and WHC (M/T value), measured 24 hours post-mortem, were used to assign SM and LD muscles to 1 of 9 quality classes (Table 3). Based on the lightness (CIEL* value) and M/T value, SM and LD muscles were classified into PE (pale and exudative), PN (pale and non-exudative), RE (reddish-pink and exudative), RN (reddish-pink and non-exudative), RD (reddish-pink and dry), DN (dark and non-exudative), and DD (dark and dry) pork. Two extreme combination of CIEL* and $\mathrm{M} / \mathrm{T}$ values resulting in PD - pale and dry, and DE dark and exudative pork quality were not identified. Generally, in SM muscles the higher percentages of PN (LW : $L=13.6 \%: 12.0 \%), R N(L W: L=34.6 \%: 33.7 \%), R D(L W: L=8.6 \%: 2.4 \%)$ and $D D(L W: L=3.7 \%: 1.2 \%)$ pork, and the lower percentages of PE (LW : $L=16.0 \%: 18.1 \%)$, RE (LW : $L=18.5 \%: 26.5 \%)$ and $D N(L W: L=4.9 \%: 6.0 \%)$ pork were determined. In contrast, in LD muscles the lower percentages of PN (LW : $L=7.4 \%: 9.6 \%), R N(L W: L=$ $24.7 \%: 18.1 \%), R D(L W: L=2.5 \%: 0.0 \%$ ) and DD ( $L W: L=1.2 \%: 1.2 \%)$ pork, and the higher percentage of PE (LW $: L=25.9 \%: 33.7 \%), R E(L W: L=33.3 \%: 27.7 \%)$ and $D N(L W: L=4.9 \%: 9.6 \%)$ pork were determined. Overall, the percentages of $P E, P N, R E, R N, R D, D N$, and DD pork were $23.5,10.7,26.5,27.7,3.4,6.4$, and $1.8 \%$, respectively.

With these seven categories of pork quality (Table 3 ) it is evident that although colour and WHC are significantly related (Table 2) their specific biochemical properties vary independently. This results are is in accordance with the conclusions of Bendall and Swatland (1988), van Laack et al. (1994), Joo et al. (1999) and Joo et al. (2000a 2000b). 


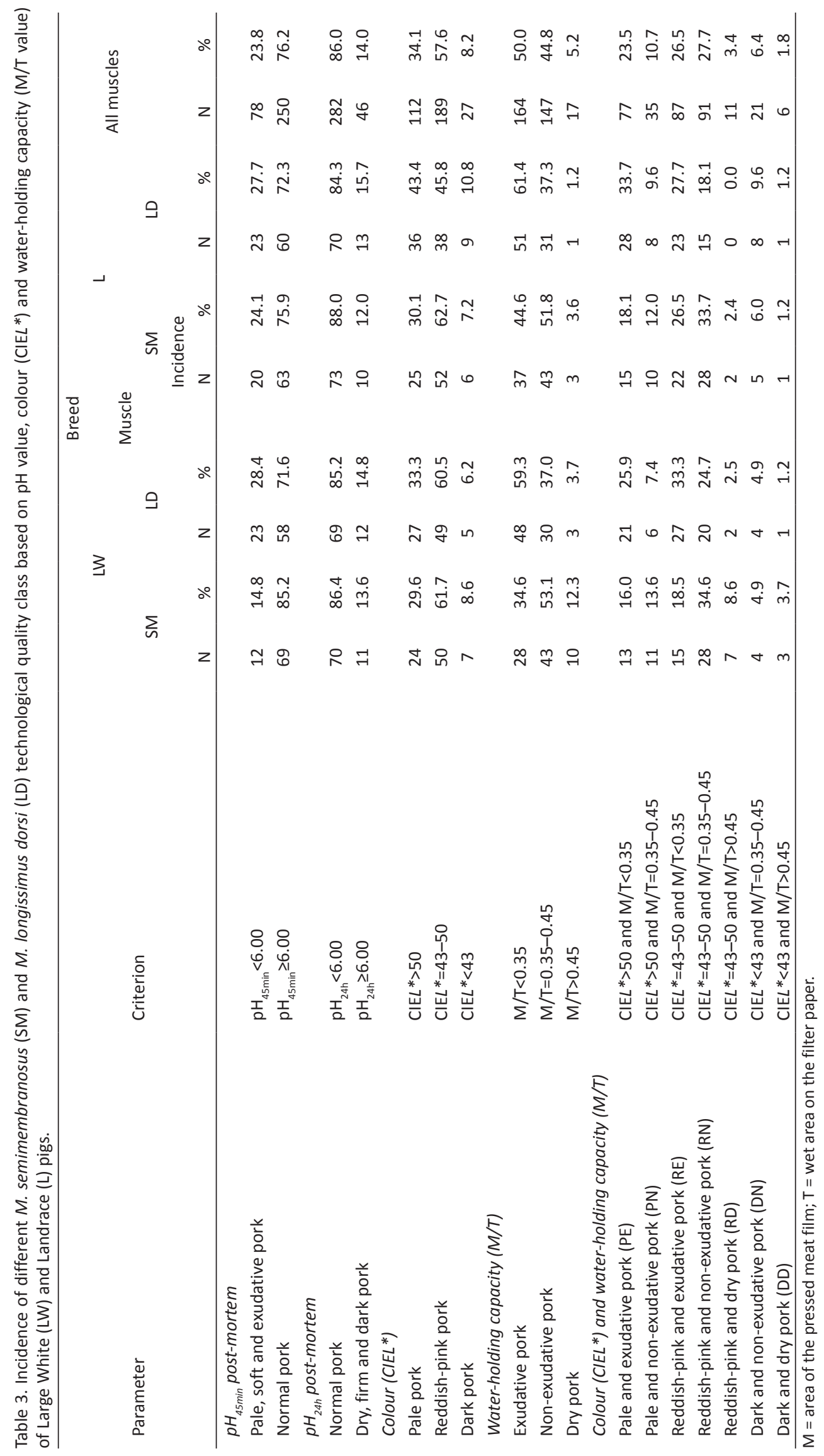


The results of this study show high percentage of pale meat $(\mathrm{PE}+\mathrm{PN}=34.1 \%)$ and exudative meat $(\mathrm{PE}+\mathrm{RE}=$ $50.0 \%$ ), i.e. the high percentage of pale and/or exudative meat ( $P E+P N+R E=60.7 \%$ ) in SM and LD muscles (Table 3). Similar incidences of PSE, PFN and RSE pork were obtained in other studies (Kauffman et al. 1992, van Laack et al. 1994, Joo et al. 2000a, O'Neill et al. 2003, van de Perre et al. 2010). It has been estimated that as much as $50 \%$ or more of the pork produced has unacceptably high purge or drip loss (Kauffman et al. 1992, Huff-Lonergan and Lonergan 2005).

\section{Composition of pork}

No significant $(p>0.05)$ interaction effect between breed and muscle was found for composition (Table 4). Also, moisture, protein, total fat and total ash content were neither affected by the breed nor by the type of muscle. The mean moisture content ranged from 75.63 ( $L D$ of $L$ ) to $75.72 \%$ (SM of $L$ ), and the mean protein content ranged from 21.62 (SM of L) to $21.79 \%$ (LD of LW). Furthermore, the mean total fat content ranged from 1.35 (SM of LW) to $1.48 \%$ ( $L D$ of $L$ ), and the mean total ash content ranged from 1.12 ( $L D$ of $L W$ and $L$ ) to $1.14 \%$ (SM of $L W$ ). Composition of all investigated groups of SM and LD muscles analyzed in the present study were in agreement with the values reported for pork (Lawrie and Ledward 2006, Australia: Greenfield et al. 2009, Denmark: National Food Institute 2009, Finland: National Institute for Health and Welfare 2009, Italy: INRAN 2009, USA: The US Department of Agriculture's 2011). As expected (Table 5), in the present study, moisture content was significantly negatively correlated with protein ( $r=-0.74$, for $L W, p<0.001 ; r=-0.43$, for $L, p<0.001$ ), total fat $(r=-0.35$, for $L W, p<0.01$; $r=-0.38$, for $L, p<0.01$ ) and total ash content ( $r=-0.44$, for $L W, p<0.001 ; r=-0.23$, for $L, p<0.05)$. Additionally, protein content was significantly negatively correlated with total fat content ( $r=-0.30$, for $L W, p<0.01 ; r=-0.60$, for $L$, $p<0.001)$. According to Keeton and Eddy (2004) the content of moisture, protein and ash decrease with increasing amounts of fat in the tissues.

Table 4. Average ( \pm SD) composition (\%) of $M$. semimembranosus (SM) and M. longissimus dorsi (LD) of Large White (LW) and Landrace (L) pigs.

\begin{tabular}{lccccccc}
\hline & \multicolumn{2}{c}{ LW } & \multicolumn{2}{c}{ Breed } & & \multicolumn{2}{c}{$p$-value } \\
Parameter & \multicolumn{2}{c}{ Muscle } & \multicolumn{2}{c}{ Muscle } & Breed & Muscle & Breed x Muscle \\
\hline Moisture & $75.67 \pm 0.46$ & $75.64 \pm 0.46$ & $75.72 \pm 0.34$ & $75.63 \pm 0.43$ & 0.758 & 0.417 & 0.670 \\
Protein & $21.74 \pm 0.38$ & $21.79 \pm 0.49$ & $21.62 \pm 0.43$ & $21.70 \pm 0.56$ & 0.177 & 0.364 & 0.827 \\
Total fat & $1.35 \pm 0.29$ & $1.39 \pm 0.28$ & $1.40 \pm 0.39$ & $1.48 \pm 0.50$ & 0.219 & 0.355 & 0.740 \\
Total ash & $1.14 \pm 0.09$ & $1.12 \pm 0.10$ & $1.13 \pm 0.10$ & $1.12 \pm 0.09$ & 0.629 & 0.294 & 0.990 \\
\hline
\end{tabular}

Table 5. Overall correlation coefficients ( $r$ ) among pork composition of Large White (LW) and Landrace (L) pigs.

\begin{tabular}{|c|c|c|c|c|c|c|}
\hline \multirow[b]{2}{*}{ Parameter } & \multicolumn{3}{|c|}{ Breed - LW } & \multicolumn{3}{|c|}{ Breed - L } \\
\hline & Protein & Total fat & Total ash & Protein & Total fat & Total ash \\
\hline Moisture & $-0.74 * * *$ & $-0.35^{* *}$ & $-0.44 * * *$ & $-0.43^{* * *}$ & $-0.38^{* *}$ & $-0.23^{*}$ \\
\hline Protein & & $-0.30 * *$ & 0.16 & & $-0.60 * * *$ & 0.07 \\
\hline Total fat & & & 0.09 & & & 0.10 \\
\hline
\end{tabular}

*indicates significant difference at $p<0.05 ; * *$ indicates significant difference at $p<0.01 ; * * *$ indicates significant difference at $p<0.001$. 


\section{Conclusion}

Investigating the effect of pig breed (Large White and Landrace) in combination with muscle (M. semimembranosus and $M$. longissimus dorsi) on technological quality and composition of pork, the following was concluded: (i) $\mathrm{T}_{24 \mathrm{~h}}$ was significantly $\left(p<0.001\right.$ ) influenced by breed, (ii) $\mathrm{T}_{45 \mathrm{~min}}, \mathrm{~T}_{24 \mathrm{~h}}, \mathrm{pH}_{45 \mathrm{~min}}$, and $\mathrm{WHC}(\mathrm{M} / \mathrm{T}$ value) were significantly $(p<0.01$ or $<0.001)$ influenced by the type of muscle, (iii) the $\mathrm{pH}$ values were not a reliable predictor for ultimate pork quality, (iv) based on the lightness (CIEL* value) and M/T value (WHC) M. semimembranosus and M. longissimus dorsi were classified into seven quality classes: PE (pale and exudative, 23.5\%), PN (pale and non-exudative, 10.7\%), RE (reddish-pink and exudative, 26.5\%), RN (reddish-pink and non-exudative, 27.7\%), RD (reddish-pink and dry, 3.4\%), DN (dark and non-exudative, 6.4\%), and DD (dark and dry, 1.8\%) pork, (v) composition was in the characteristic range for modern lean pigs.

\section{Acknowledgments}

Research was financially supported by the Ministry of Education, Science and Technological Development, Republic of Serbia, project TR31032. These results are also part of the project No 114-451-3464/2013 (Improvement of meat quality from indigenous and modern pig breeds produced in Vojvodina for the production of traditional dry fermented sausages and dry cured meat products), which is financially supported by the Provincial Secretariat for Science and Technological Development, Autonomous Province of Vojvodina, Republic of Serbia, and the project No 651-03-1251/2012-09/45 (Characterization of sensory and physicochemical attributes of protected traditional dry fermented meat products from Slovenia and Serbia) within the Serbien - Slovenia science technology cooperation for years 2012-2013.

\section{References}

Barbut, S., Sosnicki, A.A., Lonergan, S.M., Knapp, T., Ciobanu, D.C., Gatcliffe, L.J., Huff-Lonergan E. \& Wilson, E.W. 2008. Progress in reducing the pale, soft and exudative (PSE) problem in pork and poultry meat. Meat Science 79: 46-63.

Bendall, J.R. \& Swatland, H.J. 1988. A review of the relationships of pH with physical aspects of pork quality. Meat Science 24: 85-126.

Brewer, M.S., Zhu, L.G., Bidner, B., Meisinger D.J. \& McKeith. F.K. 2001. Measuring pork color: effects of bloom time, muscle, pH and relationship to instrumental parameters. Meat Science 57: 169-176.

CIE. 1976. International Commission on Illumination, Colorimetry: Official Recommendation of the International Commission on Illumination, Publication CIE No. (E-1.31). Paris, France: Bureau Central de la CIE.

ECC No. 433/1964. Council Directive of 26 June 1964 on health conditions for the production and marketing of fresh meat.

Grau, R. \& Hamm, R. 1953. Eine einfache Methode zur Bestimmung der Wasserbindung im Muskel. Naturwissenschaften 40: 29-30.

Greenfield, H., Arcot, J., Barnes, J.A., Cunningham, J., Adorno, P., Stobaus, T., Tume, R., Beilken S. \& Muller, W. 2009. Nutrient composition of Australian retail pork cuts 2005/2006. Food Chemistry 117: 721-730.

Hofmann, K., Hamm, R. \& Blüchel, E. 1982. Neues über die Bestimmung der Wasserbindung des Fleisches mit Hilfe der Filterpapierpressmethode. Die Fleischwirtschaft 62: 87-92.

Honikel, K.O. 1998. Reference methods for the assessment of physical characteristics of meat. Meat Science 49: 447-457.

Honikel, K.O. 1999. Biochemical and physico-chemical characteristics of meat quality. Meat Technology 40: 105-123.

Huff-Lonergan, E. \& Lonergan, S.M. 2005. Mechanisms of water-holding capacity of meat: The role of postmortem biochemical and structural changes. Meat Science 71: 194-204.

INRAN (Istituto Nazionale di Ricerca per gli Alimenti e la Nutrizione). 2009. Banca Dati di Composizione degli Alimenti. Cited 9 September 2013. Updated 2009. Available on the Internet: http://www.inran.it/646/tabelle_di_composizione_degli_alimenti.html

ISO 1442 1997. Meat and meat products: Determination of moisture content (Reference method). International Organisation for Standardisation, Geneva, Switzerland.

ISO 1443 1973. Meat and meat products: Determination of total fat content. International Organisation for Standardisation, Geneva, Switzerland.

ISO 2917 1999. Meat and meat products: Measurement of pH (Reference method). International Organisation for Standardisation, Geneva, Switzerland.

ISO 936 1998. Meat and meat products: Determination of total ash. International Organisation for Standardisation, Geneva, Switzerland.

ISO 937 1978. Meat and meat products: Determination of nitrogen content (Reference method). International Organisation for Standardisation, Geneva, Switzerland.

Joo, S.T., Kauffman, R.G., Kim, B.C. \& Park, G.B. 1999. The relationship of sarcoplasmic and myofibrillar protein solubility to colour and water-holding capacity in porcine longissimus muscle. Meat Science 52: 291-297. 
Joo, S.T., Kauffman, R.G., Warner, R.D., Borggaard, C., Stevenson-Barry, J.M., Lee, S., Park, G.B. \& Kim, B.C. 2000a. Objectively predicting ultimate quality of post-rigor pork musculature: I. Initial comparison of techniques. Asian Australasian Journal of Animal Sciences 13: 68-76.

Joo, S.T., Kauffman, R.G., Warner, R.D., Borggaard, C., Stevenson-Barry, J.M., Rhee, M.S., Park, B.S. \& Kim, B.C. 2000b. Objectively predicting ultimate quality of post-rigor pork musculature: II. Practical classification method on the cutting-line. Asian Australasian Journal of Animal Sciences 13: 77-85.

Kauffman, R.G., Cassens, R.G., Scherer, A. \& Meeker, D.L. 1992. Variation in pork quality. Des Moines, lowa, USA: National Pork Producers Council Publication.

Keeton, J.T. \& Eddy, S. 2004. Chemical and physical characteristics of meat/Chemical composition. In: Jensen, W. K., Carrick, D. \& Dikeman, M. (eds.) Encyclopedia of meat sciences. Oxford, UK: Elsevier Ltd. p. 210-218.

Lawrie, R.A. \& Ledward, D.A. 2006. Lawrie's meat science. 7th ed. Cambridge, England: Woodhead Publishing Ltd. \& CRC Press LLC. Lee, S., Norman, J.M., Gunasekaran, S., van Laack, R.L.J.M., Kim, B.C. \& Kauffman, R.G. 2000. Use of electrical conductivity to predict water-holding capacity in postrigor pork. Meat Science 55: 385-389.

National Food Institute Denmark. Technical University of Denmark 2009. http://www.foodcomp.dk/v7/fcdb grpsearchres.asp?MainGrp=07. Accesed 9 September 2013.

National Institute for Health and Welfare. 2011. Fineli - Finnish Food Composition Database. http://www.fineli.fi/index.php?lang=en. Accessed 9 September 2013.

Olsson, V. \& Pickova, J. 2005. The influence of production systems on meat quality, with emphasis on pork. Ambio 34: 338-343.

O'Neill, D.J., Lynch, P.B., Troy, D.J., Buckley, D.J. \& Kerry, J.P. 2003. Influence of the time of year on the incidence of PSE and DFD in Irish pigmeat. Meat Science 64: 105-111.

Rosenvold, K. \& Andersen, H.J. 2003. Factors of significance for pork quality - A review. Meat Science 64: 219-237.

Serbian Regulation 2011. Pravilnik o veterinarsko-sanitarnim uslovima, odnosno opštim i posebnim uslovima za higijenu hrane životinjskog porekla, kao i o uslovima higijene hrane životinjskog porekla. Sl. glasnik RS 11. (in Serbian).

Sevón-Aimonen, M.-L., Honkavaara, M., Serenius, T., Mäki-Tanila, A., Puonti, M. 2007. Genetic variation of loin and ham quality in Finnish Landrace and Large White pigs. Agricultural and Food Science 16: 89-102.

Smulders, F.J.M., Toldra, F., Flores, J. \& Prieto, M.1992. New technologies for meat and meat products. Utrecht, The Netherlands: Audet Tijdschriften.

StatSoft, Inc. 2011. STATISTICA (data analysis software system). Version 10. Cited 9 September 2013. Updated 2013. Available on the Internet: http://www.statsoft.com/

Swatland, H.J. 1995. Near-infrared birefringence and transmittance of pork in relation to $\mathrm{pH}$, sarcomere length, cold-shortening, and causes of paleness. Food Research International 28: 153-159.

The Danish Standard. 2007. Danish Quality Guarantee. 1st ed. Copenhagen, Denmark: Danish Meat Association.

The US Department of Agriculture's. 2011. Nutrient Data Laboratory. http://ndb.nal.usda.gov/ Accessed 9 September 2013.

Tomović, V.M., Jokanović, M.R., Petrović, Lj.S., Tomović, M.S., Tasić, T.A., Ikonić, P.M., Šumić, Z.M., Šojić, B.V., Škaljac S.B. \& Šošo, M.M. 2013. Sensory, physical and chemical characteristics of cooked ham manufactured from rapidly chilled and earlier deboned M. semimembranosus. Meat Science 93: 46-52.

Tomović, V.M., Petrović, Lj.S. \& Džinić, N.R. 2008. Effects of rapid chilling of carcasses and time of deboning on weight loss and technological quality of pork semimembranosus muscle. Meat Science 80: 1188-1193.

Tomović, V.M., Petrović, Lj.S., Tomović, M.S., Kevrešan, Ž.S. \& Džinić, N.R. 2011. Determination of mineral contents of semimembranosus muscle and liver from pure and crossbred pigs in Vojvodina (northern Serbia). Food Chemistry 124: 342-348.

UNECE (United Nations Economic Commission for Europe) standard. 2008. Porcine meat - carcases and cuts. 2006 ed. New York and Geneva: United Nations Publication.

van de Perre, V., Ceustermans, A., Leyten, J. \& Geers, R. 2010. The prevalence of PSE characteristics in pork and cooked ham - Effects of season and lairage time. Meat Science 86: 391-397.

van Laack, R.L.J.M., Kauffman, R.G., Sybesma, W., Smulders, F.J.M., Eikelenboom, G. \& Pinheiro, J.C. 1994. Is colour brightness (Lvalue) a reliable indicator of water-holding capacity in porcine muscle? Meat Science 38: 193-201.

van Oeckel, M.J., Warnants, N. \& Boucqué, C.V. 1999. Comparison of different methods for measuring water holding capacity and juiciness of pork versus on-line screening methods. Meat Science 51: 313-320.

Warner, R.D., Kauffman, R.G. \& Greaser, M.L. 1997. Muscle protein changes post mortem in relation to pork quality traits. Meat Science 45: 339-352. 